\title{
ПРОБЛЕМЫ И ПЕРСПЕКТИВЫ РАЗВИТИЯ МАЛЫХ ГОРОДОВ
}

\author{
(C) 2020 Нурсейтова Гульмира Бектургановна \\ кандидат экономических наук, старший преподаватель \\ Казахский национальный университет имени аль-Фараби, Казахстан, Алматы \\ Email: n.gulmyra@mail.ru \\ (c) 2020 Асанова Гүлжайна Батырқұлқызы \\ докторант 1-го курса по специальности «Государственное и местное управление» \\ Казахский национальный университет имени аль-Фараби, Казахстан, Алматы \\ Email: gulzhaina17@mail.ru
}

В данной статье рассматриваются проблемы малых городов и возможные пути их решения. Рассматривая роль малых городов в региональном развитии, следует отметить, что малый город является структурным элементом региона. Уровень развития региона зависит от уровня развития малых городов в их составе. Кроме того, комплексный подход к развитию малых городов с учетом основ инновационной стратегии может обеспечить конкурентоспособность и устойчивость их развития. Решение проблемы малых городов необходимо для обеспечения всестороннего развития экономики страны.

Ключевые слова: малый город, проблемы городов, факторы развития, инновации, технологии, устойчивое развитие.

\section{Введение.}

Малый город в силу своих географических, социальных, индустриальных и демографических особенностей является связующим звеном между сёлами и деревнями, с одной стороны, и средними и крупными городами, с другой.

Многие малые города являются активным, развивающимся социально-экономическим сообществом людей. В небольших городах расположены основные предприятия, транспортные узлы, кроме того, такие города традиционно имеют более удобное географическое положение. В отношениях с более крупными городами маленькие действуют как посредники между городом и деревней [1].

Малые города сегодня - это средоточие проблем экономических, социальных, экологических, политических и т.п. Без содействия решений проблем малых городов их экономическая база будет продолжать разрушаться, будет расти бедность проживающего в них населения, будет неуклонно сокращаться население страны и ухудшаться его демографическая структура [2].

В связи с несовершенствами отраслевой и производственной структуры, отсталостью технологий, тяжелой экологической обстановкой большинство малых городов не имеют возможности прогрессивного развития, они отстают от экономического и технического состояния больших городов.

Проблемы малых городов:

- В малых городах нет высших учебных заведений - это означает, что молодые люди, окончив школу, едут учиться в более крупные города, где обучают востребованным на рынке специальностям в престижных университетах и колледжах.

- Технологическое отставание - это ещё одна значимая проблема малых городов, которое подразумевает отсутствие развития современных производств и обеспеченности рабочими местами работников с высшим образованием.

- Низкий уровень инновационных технологий в производстве. Если города развиваются за счет науки и новых технологических достижений - это обеспечивает не только комфортную среду проживания, но и более качественный уровень товаров и услуг.

- Недостаточный уровень развития социально-культурной сферы. Бюджет малых городов не способен обеспечить сохранность и должную реставрацию памятников архитектуры и всех объектов культурного наследия народов. В результате памятники архитектуры 
и историческая городская застройка постепенно разрушаются под воздействием окружающей среды. Вместе с этим, малые города теряют свой неповторимый облик, свою индивидуальность, что приводит к снижению уровня посещаемости туристов и гостей [3].

- Транспортная и дорожная инфраструктура. Для решения проблемы развития транспортной инфраструктуры, увеличения безопасности дорожного движения, необходимо принять комплексные, взаимосвязанные меры, направленные, в первую очередь, на улучшение системы управления движением, решение проблемы парковки автомобилей и создание безопасных условий для пешеходного движения. Работы современных специалистов в области транспорта описывают различные методы регулирования движения на сложных дорожных развязках и автомагистралях, а также методы проектирования экономичных транспортных систем с высокой пропускной способностью [4].

Пять факторов, определяющих экономический рост в малых городах:

1. Развитие предпринимательской экосистемы - это создание условий, которые позволят поднять бизнес. Власти и местные инвесторы, в сотрудничестве с предпринимателями, должны поддержать местных новаторов.

2. Инвестиции общества, стимулирующие рост новой экономики. Успешные сообщества признают, что их жизнеспособность зависит от новых инноваций, расширенных образовательных возможностей и сильного человеческого капитала. Эти сообщества определяют активы капитала и используют эти возможности для долгосрочного экономического успеха.

3. Социальный капитал. Успешные малые сообщества создали прочную социальную структуру с глубокими и долговременными отношениями.

4. Особенные места: успешные сообщества создают яркую среду, которые люди хотят посещать.

5. Постоянный прогресс и всестороннее развитие. Неоднократно исследователи обнаруживали, что успешные, процветающие города были активными и полны решимости продвигать свое сообщество вперед, какими бы маленькими они ни были [5].

Малые города, которые входят в состав средних городов, содействует региональному и сельскому развитию некоторыми основными способами (рис. 1).

Для развития малых городов рекомендуются

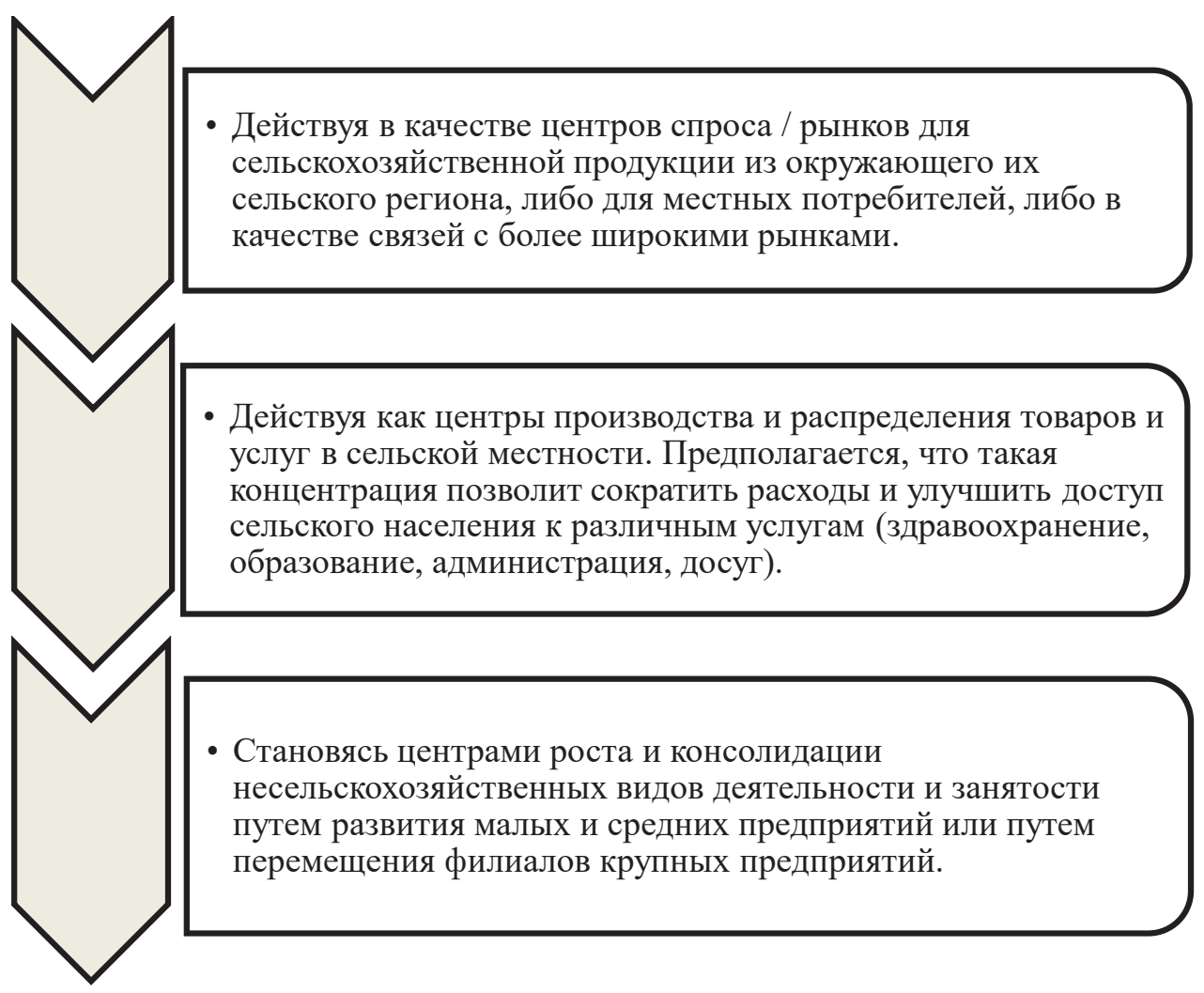

Рис. 1. Основные способы малых городов содействующих развитию региона [6]. 
следующие задачи:

- развитие культуры в малых городах, строительство и реставрация домов культуры и памятников, подготовка спортивных площадок и парков, бульваров для отдыха;

- по развитию туризма многие небольшие города имеют богатую историю и сохранили множество памятников истории, архитектуры. В этом случае, целесообразно инвестировать в развитие туризма, туристической инфраструктуры и сельского хозяйства;

- строительство медицинских центров, учебных заведений. В каждом небольшом городе невозможно построить медицинские центры с современным оборудованием или филиалы университетов с широким спектром изучаемых программ.

Несмотря на сходство направлений развития городов, их потенциала, уровня жизни, состояния социальной и производственной инфраструктуры, важно учитывать особенности каждого города. Особенности зависят от положения города в климатической зоне, относительно существующих транспортных коридоров, исторического, культурного и социальноэкономического потенциала. Поэтому адаптивная стратегия развития малых исторических городов должна иметь как общие, так и разные приоритеты территориального планирования [3].

Особенности города должны формироваться с использованием природного ландшафта. у некоторых малых городов есть реки, у некоторых есть горы, у некоторых есть долины, а у некоторых есть озера. Это щедрые дары природы, а также характеристика региона. Чтобы развивать город со своими особенностями, должна поддерживаться оригинальная пространственная структура города.

Защита сельского хозяйства имеет большое значение. Малые и средние города, как правило, нуждаются в развитии сельскохозяйственного потенциала. У них не раскрыта в полном объеме культура земледелия: сохранность урожая, вместе с тем, природы, деревьев, садов, которые имеют ценность для окружающего ландшафта. Как и в больших городах, малые города имеют преимущества в развитии промышленности и сельского хозяйства [7].

Инновационное развитие - это широкое использование новейших достижений науки и техники в различных сферах жизнедеятельности человека. Методы инновационного развития - это ряд мероприятий, ведущих к разработке и внедрению новых идей и знаний на промышленных предприятиях с целью их практического использования для удовлетворения потребностей потребителей продукции, использующих ресурсы инновационного развития. Инновационное развитие малых городов является мощным рычагом, который поможет добиться восстановления экономики, обеспечить ее структурную перестройку и насытить рынок разнообразной конкурентоспособной продукцией.

Создание благоприятной образовательной среды для подготовки квалифицированных кадров со средним и высшим образованием, создание стимулов для жителей и бизнеса, в том числе инновационного устранение административных барьеров

\section{ЧЕТЫРЕ НАПРАВЛЕНИЯ} РАБОТЫ

внедрение стандартных решений, стимулирующих экономическое развитие создание стимулов для развития инфраструктуры через межмуниципальное сотрудничество

Рис. 2. Направлении работ в развитии малых городов [8]. 
при поддержке органов государственной власти регионов и муниципальных организаций, заинтересованных промышленных предприятий, с целью повышения занятости и среднего дохода населения. Градообразующие предприятия представляют собой перспективную базу для ее реализации. Решение проблем безработицы в малых городах предполагает реализацию целого комплекса мер в области государственной и муниципальной политики. Основными направлениями деятельности являются социальная помощь безработным, регистрация безработных и выплата пособий. Большое значение придается программе переобучения в организации самозанятости в условиях конкуренции и спроса на отдельные профессии и квалификации [9].

Также, частный сектор в малых и средних городах имеет определенные преимущества:

1. В целом, низкий уровень преступности.

2. Многие города имеют достаточно хорошую унаследованную инфраструктуру (водоснабжение, канализация и электричество).

3. Транспортные расходы в малых городах, как правило, ниже. Небольшие расстояния позволяют людям чаще передвигаться пешком, что снижает транспортные расходы (однако торговля с другими центрами увеличивает транспортные расходы).

4. Собственность все еще относительно дешевая, будь то покупка или аренда.

5. Загородное сельское хозяйство часто возможно на муниципальных землях общего пользования [10].
Решение проблем малых городов приведет к улучшению условий для экономического, социального и культурного развития малых городов. В настоящее время малые города являются важнейшим структурным элементом национальной системы, выполняя функции организационно-экономических центров для сельской местности. Они оказывают значительное влияние на развитие отдельных регионов, дополняют экономическую базу региональных центров и решают проблемы транспорта, распределения и управления. Одним из решений, направленных на повышение уровня жизни в небольших городах и деревнях, является создание инновационных центров с инновационными предприятиями, расположенными за пределами крупных городов. Доведение сельских районов до новый уровень инновационного экономического развития и модернизации - эти центры, а также инновационные и технопарки, бизнес-инкубаторы могут оказать непосредственное влияние на социальноэкономический уровень окрестностей.

В будущем малые города должны стать центрами локальных систем расселения, местом концентрации производственных, социальнокультурных, организационных, обслуживающих функций сопредельных территорий. Устойчивое развитие малых городов будет способствовать улучшению функционирования национальной экономики, уменьшению дисбалансов в развитии региональных и местных систем расселения.

\section{Библиографический список}

1. Лаврова Т. Г. Роль и потенциал малых городов в развитии региона (на примере Краснодарского края). Вестник Томского государственного университета. 2015. № 399. С. 204-211.

2. Рассеко Ю. Ю. Зарубежный опыт развития малых городов.

3. Гандельсман Б.В., Чурилов Р.С. Восстановление и устойчивое развитие исторических малых городов Европейской части Российской федерации. Московский архитектурный институт (государственная академия), Москва, Россия.

4. Nikolaeva R., Sakhapov R. Improving Transport Infrastructure in the Context of the Transition to the Smart City Concept in Small Towns. EasyChair Preprint. № 3098. April 1, 2020.

5. Maher A. Five Factors Driving Economic Growth in Small Cities. https://icic.org/blog/5-strategies/

6. N Spasić,. J Petrić. The role and development perspectives of small towns in Central Serbia. - Spatium, $2006-$ scindeks.ceon.rs.

7. QIN Mengdi,. LIU Guanpeng. Strategies on Improving the Attraction of Small Towns in China, Solving Problems Caused by Migration. Tongji University, China. 49 th ISOCARP Congress 2013.

8. Экспертный совет по малым территориям стратегическое развитие малых поселений: проблемы и решения. 2017.

9. Андреев О.Е.Проблема занятости населения в малых городах и пути ее решения (на примере городского округа города Арзамас). Приволжский научный вестник. № 12-2 (52.) - 2015. Экономические науки.

10. Doreen Atkinson. Creating Access to Economic Opportunities in Small and Medium Sized Towns. October 2008. 